\title{
Effect of organic and inorganic fertilizers on yield and yield attributes of wheat variety Ujala-2015 under irrigated conditions of Balochistan
}

\author{
Amanullah ${ }^{1}$, Zulfiqar Ali Rahujo 2 , Mehdi Hassan², Muhammad \\ Yaqub $^{3}$, Muhammad Iqbal Jakhro ${ }^{1 *}$, Saeed Ahmed ${ }^{4}$, Nazeer Ahmed ${ }^{5}$, \\ Munir Ahmed Khetran ${ }^{1}$, Shafique Ahmed ${ }^{5}$, Noor Samad Naseer ${ }^{1}$ and \\ Nadeem Sadiq ${ }^{1}$ \\ 1. PARC, Balochistan Agriculture Research \& Development Center, Quetta, Balochistan-Pakistan \\ 2. PARC, Agriculture Research Institute Jaffarabad (BARDC) Balochistan-Pakistan \\ 3. PARC, Horticulture Research Institute Khuzdar (BARDC) Balochistan-Pakistan \\ 4. PARC, Costal Agriculture Research Institute Bhawani Lasbella (BARDC) Balochistan-Pakistan \\ 5. PARC, Agriculture Research Institute Turbat (BARDC) Balochistan-Pakistan \\ *Corresponding author's email: iqbal.jakhro@gmail.com \\ Citation \\ Amanullah, Zulfiqar Ali Rahujo, Mehdi Hassan, Muhammad Yaqub, Muhammad Iqbal Jakhro, Saeed Ahmed, \\ Nazeer Ahmed, Munir Ahmed Khetran, Shafique Ahmed, Noor Samad Naseer and Nadeem Sadiq. Effect of \\ organic and inorganic fertilizers on yield and yield attributes of wheat variety Ujala-2015 under irrigated \\ conditions of Balochistan. Pure and Applied Biology. Vol. 8, Issue 1, pp543-552.
}

http://dx.doi.org/10.19045/bspab.2018.700215

Received: 20/10/2018 Revised: 05/12/2018 Accepted: 10/12/2018

Online First: 14/12/2018

\section{Abstract}

The study objective was to check the effect of organic and inorganic fertilizers on wheat variety Ujala-2015 yield and yield attributes under irrigated conditions of Naseerabad and Jaffarabad Districts. The experiment was consist of four treatments i.e. T1-Farmer own practices of fertilizer N:P 90:60 kgha-1, T2-Biofertilizer+N:P 45:22.5 $\mathrm{kgha}^{-1}$, T3- Humic acid+N:P:P 45:22.5 $\mathrm{kgha}^{-1}$ and T4- Balance nutrient management N:P 60:30 kgha ${ }^{-1}$. Two years pooled data indicated that the application of Biofertilizer in combination with N-45 kgha-1 P-22.5 kgha ${ }^{-1}$ enhanced $3.4 \%$ to $21.5 \%$ grain yield and $2.5 \%$ to $22.3 \%$ fresh biomass yield as compared to the treatment-1(Farmer own practices of fertilizer N: P 90:60 kgha-1). Biofertilizer+half NP dose is a beneficial product that contains many elements which improved the soil fertility and increase the availability of macro and micro nutrient elements. Treatment- 2 significantly uptake of various macro and micronutrients such as $\mathrm{N}, \mathrm{P}, \mathrm{K}, \mathrm{Zn}, \mathrm{Fe}, \mathrm{Cu}, \mathrm{Mn}$ and $\mathrm{B}$ contents of wheat tissue. Also, soil characteristics of Naseerabad and Jaffarabad districts were evaluated overall soil physicochemical, macro and micronutrients i.e., $\mathrm{pH}, \mathrm{EC}$, lime contain $\%, \mathrm{O} . \mathrm{M}, \mathrm{N}, \mathrm{P}, \mathrm{K}$, $\mathrm{Zn}, \mathrm{Fe}, \mathrm{Cu}, \mathrm{Mn}$ and B were increased with Biofertilizer+half NP application. Biofertilizer+N:P 45:22.5 kgha ${ }^{-1}>$ Humic acid+N:P: P 45:22.5 kgha ${ }^{-1}>$ Balance Nutrient Management N:P 60:30 $\mathrm{kgha}^{-1}>$.

Keywords: Inoculum; Humic acid; Nitrogen; Phosphorous; Wheat; Yield components

Introduction

Wheat is the staple food of the people. Pakistan ranks $10^{\text {th }}$ among the wheat- producing countries of the world with an average per annum yield of 22 million tons. The wheat cultivated area in Balochistan 
0.34 million hectares with $0.663 \mathrm{~m}$ tons production which average $1,946 \mathrm{kgha}^{-1}$. The wheat cultivation of province has $4.1 \%$ area with a $3.4 \%$ production of the country. Balochistan province produces $60 \%$ of its requirement, while the lack met regarding imports from than other provinces. There has been substantial reduction in yield because of late sowing of crop, unavailability of improved seed quality, excess use of fertilizer input and not uses of Biofertilizer, improper practices, lack of rainfall during first stage of the crop and warm temperature at the time of grains formation. The climate of is extremely hot and highly humid in summer, particularly in the area adjacent to the Pat Feeder Canal, where rice cultivation takes place. The rainy season is mostly in the months of July and August. Naseerabad and Jaffarabad have largest canal irrigated land also major wheat producing districts of Balochistan. Under what cultivation area in the $0.311 \mathrm{~m}$ ha are canal irrigated and rainfed $0.30 \mathrm{~m}$ ha. The crop can be augmented without carrying more area under cultivation. Particularly, Balance use of fertilizer and Biofertilizers with combination of NP application for wheat production. Biofertilizer is well-defined as a substantial which holds living organisms that when applied to seed, plant surface, or soil, colonize the rhizosphere or the inside of plant and stimulate growth by increasing amount or accessibility of primary nutrients to the host plant [1]. Biofertilizers are well known as a significant factor of integrated plant nutrient managing for sustainable agriculture and control a great promise to increase crop yield [2]. Microbial inoculation is an important element of organic farming as the microbes help to fix atmospheric nitrogen, solubilize and activate phosphorous, translocate slight elements like zinc and copper to the plants, produce plant growth stimulating hormones, vitamins and amino acids and control plant pathogenic fungi. It increases soil health and increases crop production. Azospirillum inoculants are recommended mostly for wheat, sorghum, millets, maize, sugarcane and vegetable crops. Plant growth stimulating rhizobacteria are free living microorganisms having useful effects on plants by colonizing their roots. They include such effects as the production of phytohormones; auxin, cytokinins and gibberellins [3], enhancing release of the nutrients [4]. The microorganisms involved in $\mathrm{P}$ solubilization can enhance plant growth by increasing the efficiency of biological nitrogen fixation, enhancing the availability of other trace elements and by production of plant growth promoting substances [5]. Biofertilizer have earlier significantly improved wheat and barley yield in irrigated as well as in rainfed crops [6]. Biofertilizer treatment enhanced irrigated grain yield by $11 \%$, while the yield of rainfed barley improved by $36 \%$ grain yield of irrigated wheat increased by $24 \%$ while rainfed barley yield doubled [7]. These variances in response are recommended to be an effect of the productive level of the soil and fertilizer application. Wheat, and in specific irrigated wheat, is grown on the most fertile soils and obtains mineral fertilizers. On the conflicting, rainfed barley is full-grown on the most marginal soils with low inherent fertility; this opinion is supported by other researchers [7]. Suitable biotechnological approaches could be used to improve crop productivity in salt affected areas $[8,9]$. Moreover, salt-tolerant microorganisms may improve soil fertility through decomposition of organic matter and nutrient cycling, by fixation of atmospheric nitrogen or through production of growth hormones [10-13]. Recently, emphasis is also given on the application of traitspecific microbial inoculants that can be used for detoxification of toxicants $[14,15]$, disease suppression of pathogenic organisms [12] and stress tolerance in plants [16-18] found that eight Pseudomonas spp. strains (out of 25 isolated strains) having highest level of salt tolerance, exhibited ACC deaminize activity and also showed several growth- 
promoting characteristics. The study was conducted to investigate the effect of Azospirillum biofertilizer with the combinations of Inorganic fertilizers on wheat variety Ujala-2015 yield under the irrigated areas (Naseerabad and Jaffarabad) locations of Balochistan.

\section{Materials and methods}

Field experiments were carried out during the Rabi season of 215-16 and 216-17 at the farmers' fields of irrigated areas of Naseerabad and Jaffarabad Districts of Balochistan, to check the effect of Organic and inorganic fertilizers on growth and yield of wheat (Triticum aestivum) variety Ujala-2015. The experiment was laid out in randomized complete block design with four replications and the experiment was consist of four main treatments i.e. T1Farmer own practices of fertilizer N:P 90:60 kgha ${ }^{-1}$, T2-Biofertilizer+ N:P 45:22.5 $\mathrm{kgha}^{-1}$, T3- Humic acid+N:P:P 45:22.5 kgha $^{-1}$ and T4- Balance Nutrient Management N:P 60:30 $\mathrm{kgha}^{-1}$. Each treatment plot size was kept $250 \mathrm{~m}^{2}$ and total plot size was one acre $\left(4000 \mathrm{~m}^{2}\right)$ in each experimental location. The crop was sown on $7^{\text {th }}$ and $9^{\text {th }}$ November 2015 and 2016. The seed@100 kgha ${ }^{-1}$ and Broadcast sowing method was applied. Seeds were treated with calculated quantities of biofertilizer (A1-Q) provided by National Agricultural Research Centre, Islamabad and also seed was treated with Humic acid @ $0.5 \mathrm{kgha}^{-1}$ at the sowing time. Nitrogen and phosphorus were applied at the time of sowing in the form of urea and $\mathrm{Di}$ Ammonium Phosphate (DAP) was applied. The soil was collected form Jaffarabad and Naseerabad to investigate the nature, extent, and severity of nutrient disorders from both districts of Balochistan, the soil survey of research study sites was conducted and selected four farmers field at each district. Soil and plant sampling of each site was collected the plant tissue samples randomly selected farmer field of each district. Processed and analyzed plant samples for $\mathrm{N}, \mathrm{P}, \mathrm{K}$, and $\mathrm{B}, \mathrm{Zn}, \mathrm{Cu}, \mathrm{Fe}, \mathrm{Mn}$, was carried out by the standard method. Soil sampling collected from the depth of (0-15 and 15-30 cm). Soil samples were processed \& analyzed for physicochemical properties, macro and micro nutrients. Soil $\mathrm{pH}$ (alkalinity and basicity) and electrical conductivity (EC) soluble ions were determined in a 1:2 soil-water extract using $\mathrm{pH}$ and EC meter, respectively. Soil texture was determined by the hydrometer method [19], soil organic carbon by Walkley-Black method and corrected to organic matter by Vant Hoof's factor (1.724) [20], lime analysis by acid neutralization method [21]. Available $\mathrm{P}$ was determined by the Olsen $\mathrm{NaHCO} 3$ extraction [22] followed by colour development using ascorbic acid method as described by [23]. Exchangeable $\mathrm{K}$ was determined by extraction with $1 \mathrm{~N}$ $\mathrm{NH}_{4} \mathrm{OAC}\left(\mathrm{CH}_{3} \mathrm{COONH}_{4}\right)$ followed by subjecting the extract on an emission flame photometer as described by [24]. The extractable micronutrients $(\mathrm{Cu}, \mathrm{Fe}, \mathrm{Mn}$ and $\mathrm{Zn}$ ) were determined by (AB-DTPA) method [25] and the extracts were subjected to atomic absorption spectrophotometer (AAS).

\section{Results and discussion}

The data results before the experiment stated in 2015-16 collected soil samples from the project site and analyzed for $\mathrm{pH}$ (8.0), non-alkaline EC (3270uS), noncalcareous in nature $(6.8 \%) \mathrm{CaCO}_{3}$ the organic matter $(0.219 \%)$, Nitrite $(0.008 \%)$, Phosphors (2.1 ppm) and Potassium was found (29 ppm) shown in (Table 1). Soil were deficient in macro and micro nutrients in the nature and soil status were recorded $\mathrm{Mn}$ (0.07 ppm), Fe (0.1 ppm), Cu (0.1 $\mathrm{ppm}), \mathrm{B}(0.1 \mathrm{ppm})$ and $\mathrm{Zn}(0.5 \mathrm{ppm})$ whereas the same year same treatment-1 (Biofertilizer with the combination of inorganic fertilizer improved the soil physicochemical, macro and micronutrients $\mathrm{pH}(5.0 \%)$, EC (18\%), $\mathrm{CaCO}_{3}(28 \%)$, organic matter (8\%), Nitrite (17\%), Phosphors (59\%), Potassium (7.5\%) $\mathrm{Zn},(33 \%), \mathrm{Fe}(85 \%), \mathrm{Cu}(67 \%), \mathrm{Mn}(75 \%)$ and $\mathrm{B}(95 \%)$ respectively. 
Table 1. Mean value of Nutrients and soil physiochemical properties of Jaffarabad district 2015-16

\begin{tabular}{|c|c|c|c|c|c|}
\hline \multicolumn{2}{|c|}{ Before sowing data } & \multicolumn{4}{c|}{ After Harvesting data } \\
\hline \multicolumn{2}{|c|}{ Parameters } & Treatment-1 & Treatment-2 & Treatment-3 & Treatment-4 \\
\hline $\mathrm{pH}$ & 8.0 & 7.5 & 7.8 & 7.9 & 7.7 \\
\hline $\mathrm{EC}(\mathrm{uS})$ & 3270 & 3147 & 3090 & 3120 & 3311 \\
\hline $\mathrm{TDS}(\mathrm{ppm})$ & 207 & 305 & 751 & 452 & 331 \\
\hline $\mathrm{CaCO3 \%}$ & 6.8 & 4.6 & 3.3 & 3.5 & 3.5 \\
\hline Texture class & Clay loam & Clay loam & Clay loam & Clay loam & Clay loam \\
\hline $\mathrm{O} . \mathrm{M} \%$ & 0.21875 & 1.724 & 1.581 & 1.437 & 1.571 \\
\hline $\mathrm{N} \%$ & 0.0081 & 0.0086 & 0.0071 & 0.007 & 0.004 \\
\hline $\mathrm{P}(\mathrm{ppm})$ & 2.1 & 0.03 & 0.01 & 0.03 & 0.03 \\
\hline $\mathrm{K}(\mathrm{ppm})$ & 29 & 17.6 & 16.3 & 15.1 & 15.1 \\
\hline $\mathrm{Zn}(\mathrm{ppm})$ & 0.5 & 0.9 & 0.6 & 0.7 & 0.6 \\
\hline $\mathrm{Fe}(\mathrm{ppm})$ & 0.1 & 0.7 & 0.1 & 0.5 & 0.6 \\
\hline $\mathrm{Cu}(\mathrm{ppm})$ & 0.1 & 0.6 & 0.2 & 0.4 & 0.4 \\
\hline $\mathrm{Mn}(\mathrm{ppm})$ & 0.07 & 0.4 & 0.1 & 0.2 & 0.4 \\
\hline $\mathrm{B}(\mathrm{ppm})$ & 0.1 & 4.4 & 0.2 & 2.1 & 2.0 \\
\hline
\end{tabular}

The data contents of N, P, K, Zn, Fe, Mn, $\mathrm{Cu}$ and $\mathrm{B}$ in wheat plant tissue were obtained maximum at the vegetative growth stage (flag leaves) during period 2015-16. Macro and micronutrient content in leaves of wheat were significantly affected by Biofertilizer+Half NP dose of application. Result indicated that Biofertilizer+Half NP dose application enhanced plant absorption N, P, K, Zn, Fe, $\mathrm{Cu}, \mathrm{Mn}$ and $\mathrm{B}$ by increasing these concentrations in the leaves of wheat plants. The $\mathrm{N}$ range between (2.01-2.82 \%) and $\mathrm{P}$ was obtained from $(0.50-0.32 \mathrm{ppm})$ whereas the $\mathrm{K}$ was observed from (1.50$2.23 \mathrm{ppm})$ respectively. Micronutrients were obtained i.e., $\mathrm{Zn}$ (10.31-15.20 ppm), $\mathrm{Fe}$ (2.9-7.9 ppm), Cu (5.1-7.0 ppm), Mn (5.50-9.00 ppm) and B (0.07-0.10 ppm) was recorded in treatment-2 control (Farmers own practice full NP dose) and Biofertilizer+Half NP dose application improved plant absorption. As macro and micronutrients are often present in the soil but immobile due to unfavorable condition but when suitable climatic conditions are provided these nutrients used to be mobile and data is presented in (Table 2).

Table 2. Mean table of plant analytical data of Jaffarabad 2015-2016

\begin{tabular}{|c|c|c|c|c|}
\hline Parameters & Treatment-1 & Treatment-2 & Treatment-3 & Treatment-4 \\
\hline $\mathrm{N} \%$ & 2.8 & 2.0 & 2.5 & 2.3 \\
\hline $\mathrm{P}(\mathrm{ppm})$ & 0.3 & 0.1 & 0.1 & 0.1 \\
\hline $\mathrm{K}(\mathrm{ppm})$ & 2.2 & 1.5 & 2.1 & 2.0 \\
\hline $\mathrm{Zn}(\mathrm{ppm})$ & 15.2 & 10.3 & 12.1 & 10.4 \\
\hline $\mathrm{Fe}(\mathrm{ppm})$ & 7.9 & 2.9 & 5.4 & 4.9 \\
\hline $\mathrm{Cu}(\mathrm{ppm})$ & 7.0 & 5.1 & 6.0 & 6.5 \\
\hline $\mathrm{Mn}(\mathrm{ppm})$ & 9.0 & 5.5 & 5.9 & 6.5 \\
\hline $\mathrm{B}(\mathrm{ppm})$ & 0.1 & 0.0 & 0.0 & 0.0 \\
\hline
\end{tabular}

Data is presented in (Table 3) that the analyzed 70 soil samples of the Naseerabad and Jaffarabad districts during 2016-17 for different physicochemical and macro \& micro nutrients investigated. It has been observed that amount of various macro and micronutrients level was low and the soil was saline in reaction $\mathrm{pH}$ (7.5- 7.9), and non-alkaline EC range was (30902$3147 \mathrm{uS})$, non-calcareous in nature (3.34.6\%) $\mathrm{CaCO}_{3}$. The soil texture was determined by the Bouyocous Hydrometer 
method [26]. The soil particles size analysis indicated that the proportion of sand in the soil profile ranged between $(6.5 \%)$, silt ranged between $(37.5 \%)$ and clay ranged between $(56 \%)$. The organic matter was (0.632167-0.8335) and Nitrite range was determined from 0.003161 to $0.004168 \%$ according to the methods [27]. Phosphorus was observed low in soil and Potassium was found moderate in all treatments i.e., (0.011-0.042, 19-21 ppm). It has been observed that amount of various macro and micronutrients has been raised to a significant level in treatment 1 (Biofertilizer+Half N:P dose) and 3 (Humic acid+Half N: P dose.) where humic acid and Biofertilizer was applied. For example ratio of $\mathrm{Zn}, \mathrm{Fe}, \mathrm{Cu}, \mathrm{Mn}$ and $\mathrm{B}$ was recorded in the range of $0.1,0.1,0.2,0.05$ to 0.1 in the samples collected before sowing and was raised to $2.6,0.4,0.5,0.4$ and 1.4 respectively in treatment-1 (Biofertilizer+Half NP dose).

Table 3. Mean of soil nutrients physiochemical properties of Naseerabad district 2016-17

\begin{tabular}{|c|c|c|c|c|c|}
\hline \multicolumn{2}{|c|}{ Before sowing data } & \multicolumn{5}{c|}{ After Harvesting data } \\
\hline \multicolumn{2}{|c|}{ Parameters } & Treatment-1 & Treatment-2 & Treatment-3 & Treatment-4 \\
\hline $\mathrm{pH}$ & 8.1 & 7.5 & 7.7 & 7.9 & 7.6 \\
\hline $\mathrm{EC}(\mathrm{uS})$ & 6051 & 3410 & 5101 & 5902 & 3961 \\
\hline $\mathrm{TDS}(\mathrm{ppm})$ & 142 & 894 & 449 & 204 & 531 \\
\hline $\mathrm{CaCO3 \%}$ & 3.1 & 3.9 & 4.1 & 4.1 & 4.0 \\
\hline Texture class & Clay loam & Clay loam & Clay loam & Clay loam & Clay loam \\
\hline $\mathrm{O} . \mathrm{M} \%$ & 0.2 & 0.8 & 0.7 & 0.6 & 0.8 \\
\hline $\mathrm{N} \%$ & 0.001 & 0.004 & 0.003 & 0.003 & 0.004 \\
\hline $\mathrm{P}(\mathrm{ppm})$ & 0.05 & 0.04 & 0.02 & 0.01 & 0.03 \\
\hline $\mathrm{K}(\mathrm{ppm})$ & 25 & 21 & 20 & 19 & 20 \\
\hline $\mathrm{Zn}(\mathrm{ppm})$ & 0.1 & 2.6 & 2.4 & 0.4 & 2.5 \\
\hline $\mathrm{Fe}(\mathrm{ppm})$ & 0.1 & 0.4 & 0.2 & 0.1 & 0.3 \\
\hline $\mathrm{Cu}(\mathrm{ppm})$ & 0.2 & 0.5 & 0.2 & 0.1 & 0.3 \\
\hline $\mathrm{Mn}(\mathrm{ppm})$ & 0.05 & 0.4 & 0.2 & 0.1 & 0.2 \\
\hline $\mathrm{B}(\mathrm{ppm})$ & 0.1 & 1.4 & 1.0 & 0.1 & 1.1 \\
\hline
\end{tabular}

The data is presented in (Table 4) that the contents of $\mathrm{N}, \mathrm{P}, \mathrm{K}, \mathrm{Zn}, \mathrm{Fe}, \mathrm{Mn}, \mathrm{Cu}$ and $\mathrm{B}$ in wheat plant tissue were obtain maximum at the vegetative growth stage (flag leaves) during period 2016-17. Macro and micronutrient content in leaves of wheat were significantly affected by Biofertilizer+Half NP dose of application. Result indicated that Biofertilizer $+75 \%$ fertilizer of treatment-2 application enhanced plant absorption N, P, K, Zn, Fe, $\mathrm{Cu}, \mathrm{Mn}$ and $\mathrm{B}$ by increasing these concentrations in the leaves of wheat plants. The $\mathrm{N}$ range between $(2.05-2.44 \%)$ and $\mathrm{P}$ was obtained from $(0.10-0.34 \mathrm{ppm})$ whereas the $\mathrm{K}$ was observed from (1.55$2.33 \mathrm{ppm})$ respectively. Micronutrients were obtained i.e., $\mathrm{Zn}$ (7.67.90-13.33 ppm), $\mathrm{Fe}$ (2.5-7.7 ppm), Cu (4.6-5.8 ppm), Mn (5.45-9.11 ppm) and B (0.05-0.84 ppm) was recorded in treatment-3 (Farmers own practice of fertilizer $\mathrm{N}$ : $\mathrm{P}$ 90: $60 \mathrm{Kg} \mathrm{ha}^{-1}$ ) and T1 (Biofertilizer+75\% fertilizer of treatment-2 dose application improved plant absorption.

\section{Plant height (cm)}

The result indicated significant effect of Bio-fertilizers+N:P 45:22.5 $\mathrm{kgha}^{-1}$ on growth of plant height of wheat (Table 5). Combined application of Bio-fertilizers produced broad increase in plant height overall the treatments at all locations during both years. The highest $(112 \mathrm{~cm})$ plant height was received from the treatment- 2 from Naseerabad location- 2 followed by treatment-3 which gave $(101 \mathrm{~cm})$ plant height from the Naseerabad location-2 whereas the minimum $(95 \mathrm{~cm})$ plant height was recorded from the treatment- 4 from Jaffarabad location-1 followed by the 
treatment-1 which gave $(87 \mathrm{~cm})$ plant height from Naseerabad location-2) respectively. From the above results it maybe stated that the combined use of bio-fertilizers is useful in improving the plant height growth of wheat. Corroborative findings have been reported by [28] for wheat grown under irrigation and fertility variables.

Table 4. Mean table of Naseerabad plant analytical field data 2016-2017

\begin{tabular}{|c|c|c|c|c|}
\hline Parameters & Treatment-1 & Treatment-2 & Treatment-3 & Treatment-4 \\
\hline $\mathrm{N} \%$ & 2.4 & 2.1 & 2.0 & 2.3 \\
\hline $\mathrm{P}(\mathrm{ppm})$ & 0.3 & 0.1 & 0.1 & 0.1 \\
\hline $\mathrm{K}(\mathrm{ppm})$ & 2.3 & 1.9 & 1.5 & 2.0 \\
\hline $\mathrm{Zn}(\mathrm{ppm})$ & 13.3 & 9.9 & 7.6 & 10.5 \\
\hline $\mathrm{Fe}(\mathrm{ppm})$ & 7.7 & 2.7 & 2.5 & 4.4 \\
\hline $\mathrm{Cu}(\mathrm{ppm})$ & 5.8 & 4.9 & 4.6 & 5.2 \\
\hline $\mathrm{Mn}(\mathrm{ppm})$ & 9.11 & 5.23 & 5.45 & 5.55 \\
\hline $\mathrm{B}(\mathrm{ppm})$ & 0.84 & 0.05 & 0.05 & 0.07 \\
\hline
\end{tabular}

Table 5. Effect of organic and inorganic fertilizers on Plant height $(\mathrm{cm})$ of wheat variety Ujala-2015 (pooled data of 2015-16 and 2016-17)

\begin{tabular}{|c|c|c|c|c|c|c|c|c|}
\hline \multirow[b]{2}{*}{ Treatments } & \multicolumn{8}{|c|}{ Plant height $(\mathrm{cm})$} \\
\hline & $\begin{array}{c}\text { Naseerabad } \\
\text { Location-1 }\end{array}$ & $\begin{array}{c}\% \\
\text { Increase }\end{array}$ & $\begin{array}{c}\text { Naseerabad } \\
\text { Location-2 }\end{array}$ & $\begin{array}{c}\% \\
\text { Increase }\end{array}$ & $\begin{array}{l}\text { Jaffarabad } \\
\text { Location-1 }\end{array}$ & $\begin{array}{c}\% \\
\text { Increase }\end{array}$ & $\begin{array}{l}\text { Jaffarabad } \\
\text { Location-2 }\end{array}$ & $\begin{array}{c}\% \\
\text { Increase }\end{array}$ \\
\hline $\begin{array}{c}\text { T1-Farmer own } \\
\text { practices of } \\
\text { fertilizer } \mathrm{N}: \mathrm{P} \\
90: 60 \mathrm{kgha}^{-1}\end{array}$ & 90 & - & 87 & - & 88 & - & 89 & - \\
\hline $\begin{array}{l}\text { T2-Biofertilizer+ } \\
\text { N:P 45:22.5 } \text { kgha }^{-1}\end{array}$ & 110 & 18.2 & 112 & 22.3 & 108 & 18.5 & 108 & 17.6 \\
\hline $\begin{array}{c}\text { T3- Humic } \\
\text { acid+N:P 45:22.5 } \\
\text { kgha }^{-1}\end{array}$ & 101 & 10.9 & 99 & 12.2 & 97 & 9.3 & 100 & 11.0 \\
\hline $\begin{array}{c}\text { T4- Balance } \\
\text { Nutrient } \\
\text { Management N:P } \\
\text { 60:30 kgha' } 1\end{array}$ & 98 & 8.2 & 97 & 10.3 & 95 & 7.4 & 98 & 9.2 \\
\hline
\end{tabular}

\section{Number of tillers $/ \mathbf{m}^{2}$}

The data revealed that through the Biofertilizer+N:P 45:22.5 $\mathrm{kgha}^{-1}$ applications showed to increase number of tillers $/ \mathrm{m}^{2}$ at all locations, the results were significant in (Table 6). The highest (457) number of tillers $/ \mathrm{m}^{2}$ was received from the treatment-2 from Jaffarabad location-2 followed by treatment- 3 which produced (418) number of tillers $/ \mathrm{m}^{2}$ from same location-2 while the minimum (355) number of tillers $/ \mathrm{m}^{2}$ was gave by the treatment-4 from Naseerabad location-2 followed by the treatment- 1 which received (335) number of tillers $/ \mathrm{m}^{2}$ from same location-2) correspondingly. The similar kind of study was carried out by [29] who described that a treatment getting Phosphorous+ Azotobacter enhanced number of tillers $/ \mathrm{m}^{2}$ of wheat crop.

Total Dry Matter (TDM) kgha-1

The data indicated that the use of biofertilizer with combination of NP increased total dry matter yield at all locations (Table 7). At the Naseerabad location-1 the treatment-2 Biofertilizer + $\mathrm{N}: \mathrm{P}$ 45:22.5 $\mathrm{kgha}^{-1}$ significantly out yielded all the high mineral fertilizer treatments. The highest (12830) total dry matter kgha ${ }^{-1}$ was received from treatment- 2 followed by treatment-3 which gave (11350) total dry matter $\mathrm{kgha}^{-1}$ from the Naseerabad location 
-1whereas the lowest (9970) total dry matter $\mathrm{kgha}^{-1}$ was produced by treatment- 4 from Jaffarabad location-1 followed by treatment-1 which gave (10320) total dry matter $\mathrm{kgha}^{-1}$ from Jaffarabad location-2 respectively.

Table 6. Effect of organic and inorganic fertilizers on Number of tillers $/ \mathrm{m}^{2}$ of wheat variety Ujala-2015 (pooled data of 2015-16 and 2016-17)

\begin{tabular}{|c|c|c|c|c|c|c|c|c|}
\hline \multirow[b]{2}{*}{ Treatments } & \multicolumn{8}{|c|}{ Number of tillers/m-2 } \\
\hline & $\begin{array}{c}\text { Naseerabad } \\
\text { Location-1 }\end{array}$ & $\begin{array}{c}\% \\
\text { Increase }\end{array}$ & $\begin{array}{l}\text { Naseerabad } \\
\text { Location-2 }\end{array}$ & $\begin{array}{c}\% \\
\text { Increase }\end{array}$ & $\begin{array}{l}\text { Jaffarabad } \\
\text { Location-1 }\end{array}$ & $\begin{array}{c}\% \\
\text { Increase }\end{array}$ & $\begin{array}{l}\text { Jaffarabad } \\
\text { Location-2 }\end{array}$ & $\begin{array}{c}\% \\
\text { Increase }\end{array}$ \\
\hline $\begin{array}{c}\text { T1-Farmer own } \\
\text { practices of } \\
\text { fertilizer N:P } \\
90: 60 \text { kgha }^{-1} \\
\end{array}$ & 340 & - & 335 & - & 350 & - & 362 & - \\
\hline $\begin{array}{l}\text { T2-Biofertilizer+ } \\
\text { N:P 45:22.5 kgha } \\
\end{array}$ & 430 & 20.9 & 410 & 18.3 & 419 & 16.5 & 457 & 20.8 \\
\hline $\begin{array}{c}\text { T3- Humic } \\
\text { acid+N:P 45:22.5 } \\
\text { kgha }^{-1}\end{array}$ & 402 & 15.4 & 390 & 14.1 & 384 & 8.8 & 418 & 13.4 \\
\hline $\begin{array}{c}\text { T4- Balance } \\
\text { Nutrient } \\
\text { Management N:P } \\
\text { 60:30 kgha } \\
\end{array}$ & 357 & 4.7 & 355 & 5.6 & 375 & 6.6 & 379 & 4.5 \\
\hline
\end{tabular}

Table 7. Effect of organic and inorganic fertilizers on Total Dry Matter of wheat variety Ujala-2015 (pooled data of 2015-16 and 2016-17)

\begin{tabular}{|c|c|c|c|c|c|c|c|c|}
\hline \multirow[b]{2}{*}{ Treatments } & \multicolumn{8}{|c|}{ Total Dry Matter (TDM) kgha-1 } \\
\hline & $\begin{array}{l}\text { Naseerabad } \\
\text { Location-1 }\end{array}$ & $\begin{array}{c}\% \\
\text { Increase }\end{array}$ & $\begin{array}{l}\text { Naseerabad } \\
\text { Location-2 }\end{array}$ & $\begin{array}{c}\% \\
\text { Increase }\end{array}$ & $\begin{array}{l}\text { Jaffarabad } \\
\text { Location-1 }\end{array}$ & $\begin{array}{c}\% \\
\text { Increase }\end{array}$ & $\begin{array}{l}\text { Jaffarabad } \\
\text { Location-2 }\end{array}$ & $\begin{array}{c}\% \\
\text { Increase }\end{array}$ \\
\hline $\begin{array}{c}\text { T1-Farmer own } \\
\text { practices of } \\
\text { fertilizer N:P } \\
90: 60 \mathrm{kgha}^{-1}\end{array}$ & 9970 & - & 9890 & - & 9660 & - & 10320 & - \\
\hline $\begin{array}{c}\text { T2-Biofertilizer+ } \\
\text { N:P 45:22.5 kgha }\end{array}$ & 12830 & 22.3 & 12010 & 17.6 & 11980 & 19.4 & 12350 & 16.4 \\
\hline $\begin{array}{c}\text { T3- Humic } \\
\text { acid+N:P 45:22.5 } \\
\text { kgha }^{-1} \\
\end{array}$ & 11350 & 12.2 & 11360 & 12.9 & 10820 & 10.7 & 11210 & 7.9 \\
\hline $\begin{array}{c}\text { T4- Balance } \\
\text { Nutrient } \\
\text { Management N:P } \\
\text { 60:30 kgha' }\end{array}$ & 10720 & 7.0 & 10660 & 7.2 & 9970 & 3.1 & 10590 & 2.5 \\
\hline
\end{tabular}

Grain Yield kgha-1

The data also exposed in (Table 8) that the effect of Biofertilizer+N:P 45:22.5 kgha ${ }^{-1}$ fertilizers were significant and gave excellent performance than other treatments. The maximum (4410 $\left.\mathrm{kgha}^{-}{ }^{1}\right)$ grain yields was received by the treatment2 (Biofertilizer+N:P 45:22.5 $\mathrm{kgha}^{-1}$ ) from Jaffarabad location-2 followed by treatment-3 (Humic acid+N:P 45:22.5 $\mathrm{kgha}^{-1}$ ) which produced (4020 kgha- $\left.{ }^{1}\right)$ grain yield from the same Jaffarabad location-2 whereas the minimum (3590 kgha- ${ }^{1}$ ) grain yields were received by the treatment 4 (Balance Nutrient Management N:P 60:30 kgha $^{1}$ ) from Jaffarabad location-2 followed by treatment-4 (Farmer own practices of fertilizer N:P 90:60 $\mathrm{kgha}^{-1}$ ) which produced (3290 kgha- ${ }^{1}$ ) grain yields from Naseerabad location-2 respectively. 
Table 8. Effect of organic and inorganic fertilizers on Grain Yield of wheat variety Ujala2015 (pooled data of 2015-16 and 2016-17)

\begin{tabular}{|c|c|c|c|c|c|c|c|c|}
\hline \multirow[b]{2}{*}{ Treatments } & \multicolumn{8}{|c|}{ Grain Yield kgha-1 } \\
\hline & $\begin{array}{c}\text { Naseerabad } \\
\text { Location-1 }\end{array}$ & $\begin{array}{c}\% \\
\text { Increase }\end{array}$ & $\begin{array}{c}\text { Naseerabad } \\
\text { Location-2 }\end{array}$ & $\begin{array}{c}\% \\
\text { Increase }\end{array}$ & $\begin{array}{l}\text { Jaffarabad } \\
\text { Location-1 }\end{array}$ & $\begin{array}{c}\% \\
\text { Increase }\end{array}$ & $\begin{array}{l}\text { Jaffarabad } \\
\text { Location-2 }\end{array}$ & $\begin{array}{c}\% \\
\text { Increase }\end{array}$ \\
\hline $\begin{array}{c}\text { T1-Farmer own } \\
\text { practices of fertilizer } \\
\text { N:P 90:60 } \mathrm{kgha}^{-1}\end{array}$ & 3390 & - & 3290 & - & 3340 & - & 3470 & - \\
\hline $\begin{array}{c}\text { T2-Biofertilizer+ } \\
\text { N:P 45:22.5 kgha }\end{array}$ & 4320 & 21.5 & 4030 & 18.4 & 4010 & 16.7 & 4410 & 21.3 \\
\hline $\begin{array}{c}\text { T3- Humic acid+N:P } \\
45: 22.5 \mathrm{kgha}^{-1}\end{array}$ & 4000 & 15.3 & 3830 & 14.1 & 3680 & 9.3 & 4020 & 13.7 \\
\hline $\begin{array}{c}\text { T4- Balance Nutrient } \\
\text { Management N:P } \\
\text { 60:30 kgha }\end{array}$ & 3560 & 4.7 & 3490 & 5.72 & 3490 & 4.3 & 3590 & 3.4 \\
\hline
\end{tabular}

\section{Conclusion}

The main impacts of biofertilizer application to agricultural soils can be summarized as it is useful soil reclamation by improving soil organic matter content, soil structure and increase crop production. Crop yields responded will be depending on the type of biofertilizer and with combination of inorganic fertilizers. Application of biofertilizer with N:P 75 $\mathrm{kgha}^{-1}$ significantly increased the growth and yield of wheat crop and decreasing the soil $\mathrm{pH}$ in the saline soil. In both Districts the treatment-1 (Biofertilizer and $75 \%$ of treatment-2 fertilizers application) performed better than other treatments. The treatment-1 (Biofertilizer and $75 \%$ of treatment-2 fertilizers application) produced $07 \%$ to $12 \%$ more wheat grain yield than other treatments. Therefore, it is concluded that the minimum use of chemical fertilizers, promote the use of biofertilizer with combination of $\mathrm{N}$ : $\mathrm{P}$ fertilizers (chemical) as the result improving soil structure and enhanced over all yield of the crop.

\section{Authors' contributions}

Conceived and designed the experiments: Amanullah, ZA Rahujo, $\mathrm{H}$ Mehdi \& M Yaqub, Performed the experiments: Amanullah, MI Jakhro, NS Naseer \& N Sadiq, Analyzed the data: S Ahmed, N Ahmed \& MA Kehtran, Contributed reagents/ materials/ analysis tools: Amanullah, NS Naseer \& N Sadiq, Wrote the paper: Amanullah, NS Naseer \& MI Jakhro.

\section{References}

1. Vessey JK (2003). Plant growth promoting rhizobacteria as biofertilizers. Plant and Soil 255(2): 571-586.

2. Altuhaish A, Hamim \& Tjahjoleksono A (2014). Biofertilizer effects in combination with different drying system and storage period on growth and production of tomato plant under field conditions. Emirates $J$ of Food and Agri 26(8): 716-722.

3. García de Salamone IE, Hynes RK \& Nelson LM (2001). Cytokinin production by plant growth promoting rhizobacteria and selected mutants. Canadian J of Microbio 47(5): 404-11.

4. Nautiyal CS, Bhadauria S, Kumar P, Lal H, Mondal R \& Verma D (2000). Stress induced phosphate solubilization in bacteria isolated from alkaline soils. FEMS Micro Letters 182(2): 291-6.

5. Gyaneshwar P, Kumar GN, Parekh LJ \& Poole PS (2002). The role of soil microorganisms in improving $P$ nutrition of plants. Plant Soil 245(2): 83-93.

6. Pauw De, Mirghasemi EA, Ghaffari A \& Nseir B (2008). Agro ecological zones of Karkheh River, Basin. Research Report, ICARDA, Aleppo, Syria. 
7. Ali S, Hamza M, Amin G, Fayaz M, Monib M \& Hegazi N (2005). Production of biofertilizer using baker's yeast effluent and their application to wheat and barley grown in north Sinal deserts. Soil Sci 51(6): 589-604.

8. Naz I, Bano A, Rehman B, Pervaiz S, Iqbal M, Sarwar A \& Yasmin F (2012). Potential of Azotobacter vinelandii Khsr1 as bioinoculant. African $J$ of Biotec 11(45): 10368-10372.

9. Zahir ZA, Arshad M, Frankenberger WT (2004). Plant growth promoting rhizobacteria: applications and perspectives in agriculture. Advances in Agro 81: 97-168.

10. Sturz AV \& Nowak J (2000). Endophytic communities of rhizobacteria and the strategies required to create yield enhancing associations with crops. Appl Soil Eco 15(2000): 183-190.

11. Magda MA, El-Sabbagh SM, ElShouny WA \& Ebrahim MKH (2003). Physiological Response of Zea mays to $\mathrm{NaCl}$ Stress with Respect to Azotobacter chroococcum and Streptomyces niveus. Pak J of Bio Sci 6(24): 2073-2080.

12. Sindhu SS, Rakshiya YS \& Sahu G (2009). Biological control of soilborne plant pathogens with rhizosphere bacteria. Pest Techonology.

13. Wu CH, Bernard SM, Andersen GL \& Chen W (2009). Developing microbeplant interactions for applications in plant-growth promotion and disease control, production of useful compounds, remediation and carbon sequestration. Microbial Biotec 2(4): 428-40.

14. De-Bashana LE, Hernandez JP \& Bashan Y (2012). The potential contribution of plant growthpromoting bacteria to reduce environmental degradation-A comprehensive evaluation. Appl Soil Eco 61(2012): 171-189.

15. Weyens N, Lelie VDD, Taghavi S,
Newman L \& Vangronsveld J (2009). Exploiting plant-microbe partnerships to improve biomass production and remediation. Trends in Biotec 27(10): 591-8.

16. Nadeem SM, Zahir ZA, Naveed M \& Arshad M (2007). Preliminary investigations on inducing salt tolerance in maize through inoculation with rhizobacteria containing ACC deaminase activity. Canadian $J$ of Micro 53(10): 1141-9.

17. Yang J, Kloepper JW \& Ryu CM (2008). Rhizosphere bacteria help plants tolerate abiotic stress. Trends in Plant Sci 14(1): 1-4.

18. Rashid S, Charles TC \& Glick BR (2012). Isolation and characterization of new plant growth-promoting bacterial endophytes. Appl Soil Eco 61: 217-224.

19. Bouyoucos GH (1962). A recalibration of the hydrometer method for making mechanical analysis of soils. Agron J. 43: 434-438.

20. Jackson ML (1962). Soil Chemical Analysis. An Advanced Course. University of Wisconsin Madison, Wise. pp 47-88.

21. Jackson ML (1969). Soil Chemical Analysis. Constable Co. Ltd., London.

22. Olsen SR, CV Cole, FS Watanabe, LA Dean (1954). Estimation of available phosphorus in soil by extraction with sodium bicarbonate. U.S. Dept. Agric. Circ. 939, Washington DC.

23. Murphy J, Riley JP (1962). A modified single solution Brady NC, Weil RR (2008). The Nature and Properties of Soils. 14th Edition. Pearson PrenticeHall Inc., Upper Saddle River, New Jersey, USA pp 978.

24. Knudsen D, Peterson GA, Pratt PF (1982). Lithium, sodium and potassium In Methods of Soil Analysis, Part 2: Chemical and Microbiological Properties. Page AL (ed.). American Society of Agronomy, Madison, WI, USA pp 225-245.

25. Soltanpour PN, Schwab AP (1977). 
Use of NH4 HCO3-DTPA soil test to evaluate elemental availability and toxicity. Comm. Soil. Sci Plant Anal 16: 323-338.

26. Moodie CD, Smith HW \& McCreey RA (1954). Laboratory manual for soil fertility. State College of Washington, Mineograph, Pullman, Washington DC, USA pp 32-9.

27. Walkley A (1947). A critical examination of a rapid method for determination of organic carbon in soils - effect of variations in digestion conditions and of inorganic soil constituents. Soil Sci 63: 251-257.

28. Sharma A \& Singh H (2008). Dry matter accumulation pattern of wheat (Triticum aestivum) as influenced by integrated nutrient management and irrigation. Adv in Plant Sci 21(2): 429432.

29. Mohammad I (2002). The effect of fertilizer $P$ and Azotobacterization applied alone and in combination on the yield, yield components, $\mathrm{N}$ and $\mathrm{P}$ accumulation by wheat. Pak J Soil Sci 21: 45-50. 